\title{
North Atlantic right whale Eubalaena glacialis occurrence in offshore wind energy areas near Massachusetts and Rhode Island, USA
}

\author{
S. M. Leiter ${ }^{1, *}$, K. M. Stone ${ }^{1}$, J. L. Thompson ${ }^{2}$, C. M. Accardo ${ }^{2}$, B. C. Wikgren ${ }^{1}$, \\ M. A. Zani ${ }^{1}$, T. V. N. Cole ${ }^{3}$, R. D. Kenney ${ }^{4}$, C. A. Mayo ${ }^{2}$, S. D. Kraus ${ }^{1}$ \\ ${ }^{1}$ New England Aquarium, Boston, MA 02110, USA \\ ${ }^{2}$ Center for Coastal Studies, Provincetown, MA 02657, USA \\ ${ }^{3}$ NOAA Northeast Fisheries Science Center, Woods Hole, MA 02543, USA \\ ${ }^{4}$ University of Rhode Island Graduate School of Oceanography, Narragansett, RI 02882, USA
}

\begin{abstract}
Recent surveys of wind energy areas offshore of Massachusetts and Rhode Island (USA) have demonstrated that they encompass habitat used by the Endangered North Atlantic right whale Eubalaena glacialis. Prior to 2011, little systematic survey effort had been conducted in the area. The Bureau of Ocean Energy Management and the state of Massachusetts supported $3.5 \mathrm{yr}$ of twice-monthly aerial surveys by the Northeast Large Pelagic Survey Collaborative (NLPSC). Additional survey teams including the Northeast Fisheries Science Center and the Center for Coastal Studies have collected sightings data in the region. Data systematically collected by the NLPSC allowed analyses of monthly sightings rates, sightings per unit effort, and hot spots which provided information on current temporal and spatial use patterns. Abundance estimates for each season-year (i.e. a 3 mo period within a given survey year) were calculated. Behaviors observed included feeding and surface active groups. Photo-identification of whales since 2010 yielded a minimum count of 196 unique individuals (annual average $=35$ ), or over one-third of the current population estimate. Analyses of demographics of these individuals revealed that 34 known calving females (30\% of the total currently presumed alive) visited the study area. These results demonstrate consistent annual use of this area by a significant portion of the E. glacialis population, with a strong correlation between season and presence. These findings can inform management activities and development planning, and be used as a baseline dataset for assessing long-term impacts to the species.
\end{abstract}

KEY WORDS: North Atlantic right whale $\cdot$ Eubalaena glacialis · Wind energy area · Distribution · Abundance $\cdot$ Behavior $\cdot$ Demographics

\section{INTRODUCTION}

North Atlantic right whales Eubalaena glacialis are listed as Endangered under the US Endangered Species Act and on the IUCN Red List (Reilly et al. 2012). The most recent 'best estimate' for the species' abundance based on photographic records was 526 individuals (Pettis \& Hamilton 2015). E. glacialis use the waters along the entire eastern seaboard of North America, from Florida to Iceland (Winn et al. 1986,

*Corresponding author: sleiter@neaq.org
Knowlton et al. 1992, Jacobsen et al. 2004). Important feeding habitats for the species include the Bay of Fundy (Kraus et al. 1982), the Great South Channel (Kenney et al. 1995), Georges Basin and the northern edge of Georges Bank, east of Cape Cod and south of Nova Scotia (Waring et al. 2015), Cape Cod Bay (Hamilton \& Mayo 1990, Mayo \& Marx 1990, Nichols et al. 2008), and the Nova Scotian shelf (Stone et al. 1988). E. glacialis calving occurs primarily off the coasts of Florida and Georgia (Kraus et al. 1986a),

(C) The authors and, outside the USA, the US Government 2017. Open Access under Creative Commons by Attribution Licence. Use, distribution and reproduction are unrestricted. Authors and original publication must be credited.

Publisher: Inter-Research · www.int-res.com 
although newborn calves and other very small calves have been reported in other areas, including Massachusetts waters (Patrician et al. 2009). Feeding grounds in New England waters and the calving grounds adjacent to Florida and Georgia were federally designated as critical habitats in 1994 (NMFS 1994). In early 2016, the federally designated critical habitats were amended and expanded by 25227 square nautical miles (n miles) to encompass larger areas - the Northeastern US foraging area and the Southeastern US calving area (NOAA 2016). However, additional sighting records indicate that further E. glacialis habitats may exist, and that existing habitat use patterns may be changing (Weinrich et al. 2000, Cole et al. 2007, 2013, Whitt et al. 2013, Khan et al. 2014).

Primary threats to E. glacialis include vessel strikes (Knowlton \& Kraus 2001, Kraus et al. 2005, Knowlton \& Brown 2007, Van der Hoop et al. 2013) and entanglement in fixed fishing gear, with over $80 \%$ of the population bearing scars from interactions with gear (Knowlton et al. 2012). In addition, noise generated by ship traffic decreases the ability of E. glacialis to hear each other (Clark et al. 2007, 2009, Hatch et al. 2012), may change behavior (Parks et al. 2011), and can increase stress hormones in E. glacialis (Rolland et al. 2012). E. glacialis also face environmental stressors such as algal toxins, climate-driven ocean changes, and reduced prey availability (Rolland et al. 2007, Doucette et al. 2012, Fortune et al. 2013).

In the context of the many existing anthropogenic and environmental stressors on this species, the possible additional impacts of offshore wind farm construction, installation, and operation are not fully understood. Pile-driving during construction, if not properly mitigated, may create harmful or disruptive levels of sound (Nedwell \& Howell 2004, Madsen et al. 2006, Weilgart 2007). Other development concerns include higher collision risks due to increased vessel traffic, modification of food web dynamics, operational noise, sediment disturbance, and pollution (Carstensen et al. 2006, Madsen et al. 2006, Bailey et al. 2014, Bergström et al. 2014). Existing offshore wind facilities are primarily in European waters, where large whales do not commonly occur. Therefore, published effects studies have focused on harbor porpoises, seals, and birds (Carstensen et al. 2006, Bailey et al. 2014, Bergström et al. 2014).

Offshore wind energy development in the USA requires comprehensive assessments of biological resources within lease areas. Two federally designated wind energy areas (WEAs) are located offshore of the eastern USA near Massachusetts and Rhode
Island. In 2011, the Massachusetts Clean Energy Center (MassCEC) and the Executive Office of Energy and Environmental Affairs contracted the Northeast Large Pelagic Survey Collaborative (NLPSC) consisting of the New England Aquarium, the Center for Coastal Studies (CCS), Cornell University, and the University of Rhode Island to conduct aerial surveys for marine mammals and sea turtles in the WEA offshore of southern Massachusetts (MA WEA). This initial contract included the MA WEA as well as the additional areas of interest (AOI) for energy development known as Muskeget Channel and the Northeast Offshore Renewable Energy Innovation Zone (NOREIZ; Fig. 1). In 2012, the Bureau of Ocean Energy Management (BOEM) joined with the MassCEC and extended the contract to include the additional lease blocks known as the Rhode Island/ Massachusetts (RIMA) WEA (Fig. 1). Prior to the start of this baseline assessment, the only systematic aerial surveys that collected E. glacialis data within the WEAs were conducted by the Cetacean and Turtle Assessment Program (CETAP, 1978-1982), and additional surveys flown by the Northeast Fisheries Science Center (NEFSC/NOAA).

Here we report the spatial and temporal habitatuse patterns of E. glacialis, using sightings and photoidentification data collected by the NLPSC, NEFSC, CCS, and others from January 2010 to June 2015 in the proposed WEAs, AOI, and surrounding waters. Behavior and demography data were analyzed to determine habitat-use patterns and to characterize the subset of E. glacialis using the WEAs, in order to inform management and conservation efforts.

\section{MATERIALS AND METHODS}

\section{Aerial surveys}

The NLPSC conducted 3.5 yr of twice-monthly aerial surveys in the WEAs between October 2011 and June 2015. The NLPSC survey area was designed to include the MA WEA and AOI, and was expanded to include the RIMA WEA in December of 2012 (Fig. 1). Line-transect surveys were used to estimate the abundance and describe the spatial distribution of species (Buckland et al. 1993, Brown et al. 2007), with a particular focus on Eubalaena glacialis, which had been previously reported in the WEAs (Kenney \& Vigness-Raposa 2010).

Aerial surveys were conducted from a high-winged Cessna 337 Skymaster (0-2A) with 2 observers positioned on either side of the aircraft employing a scan- 


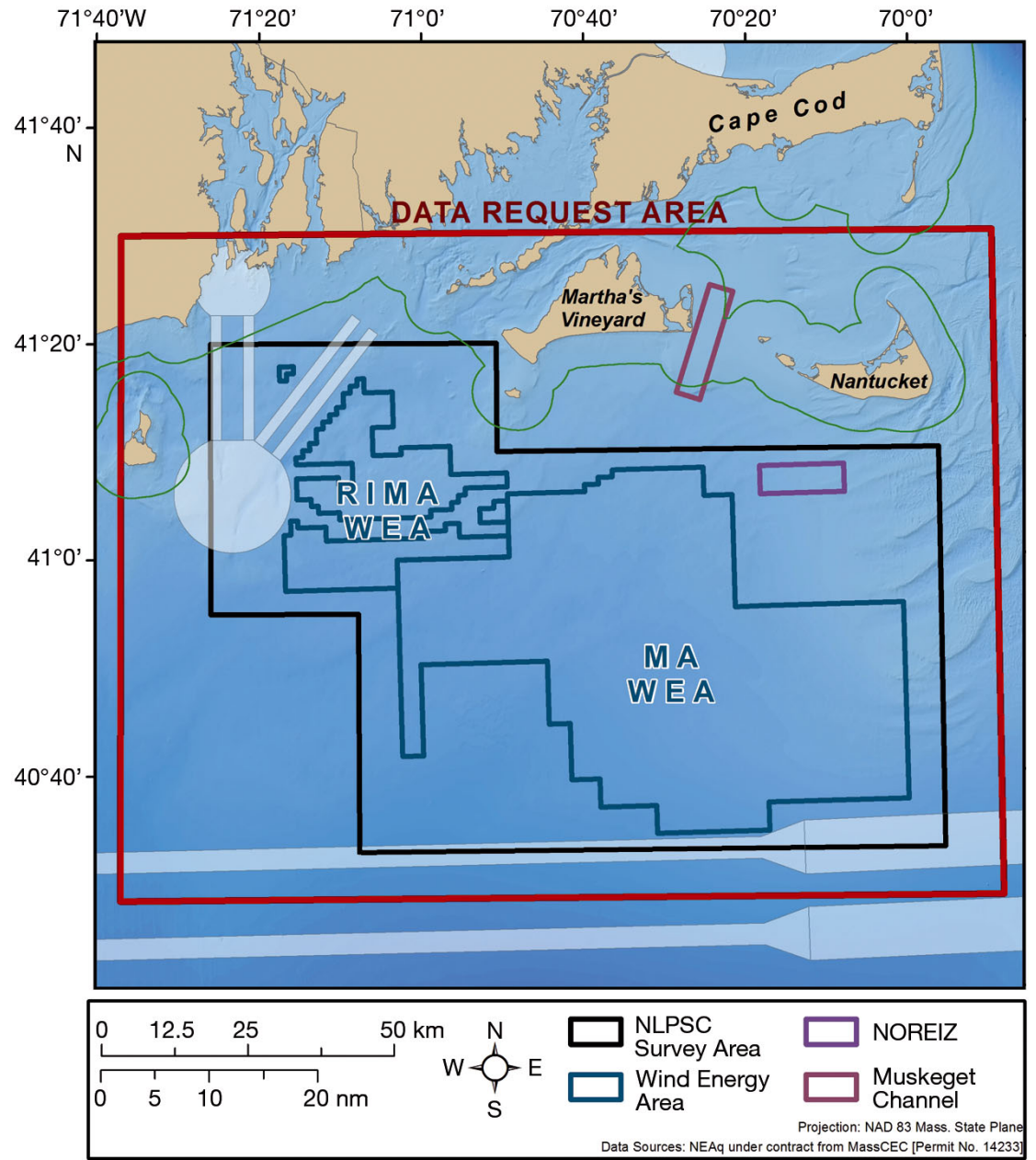

Fig. 1. Northeast Large Pelagic Survey Collaborative (NLPSC) survey area, encompassing the Massachusetts Wind Energy Area (MA WEA), the Rhode Island/Massachusetts Wind Energy Area (RIMA WEA), and the Muskeget Channel and the Northeast Offshore Renewable Energy Innovation Zone (NOREIZ) Areas of Interest. The study area is shown with a black border, and the Data Request Area is shown with a red border. Existing shipping lanes are depicted in light blue

ning pattern out to $3.7 \mathrm{~km}(2 \mathrm{n}$ miles $)$ and using Nikon binoculars $\left(8 \times 42,6.3^{\circ}\right.$ field of view) to confirm sighting cues (Brown et al. 2007, Taylor et al. 2014). Survey transects were evenly spaced at $13 \mathrm{~km}$ ( $7 \mathrm{n}$ miles) apart, and flight plans were selected at random from a pool of 18 options. Surveys were flown under visual flight rules at an altitude of $305 \mathrm{~m}(1000 \mathrm{ft})$ and a groundspeed of 100 knots $\left(185 \mathrm{~km} \mathrm{~h}^{-1}\right)$. Preferred environmental conditions included a minimum ceiling of $610 \mathrm{~m}(2000 \mathrm{ft})$, visibility greater than $9 \mathrm{~km}$ ( $5 \mathrm{n}$ miles), wind speed of less than 10 knots $\left(19 \mathrm{~km} \mathrm{~h}^{-1}\right)$, and a Beaufort sea state of 4 or less.

Sightings of marine species were recorded in a format consistent with the North Atlantic Right Whale Consortium (NARWC) Database guidelines
(Kenney 2011). A computer data-logging system automatically recorded survey parameters (latitude, longitude, heading, altitude) at frequent intervals (every 2-5 s) (Taylor et al. 2014). Sighting locations were recorded when the detection was abeam of the aircraft, and distance in $\mathrm{n}$ miles from the transect line was estimated in the following classes: within $1 / 8 ; 1 / 8$ to $1 / 4 ; 1 / 4$ to $1 / 2 ; 1 / 2$ to $1 ; 1$ to $2 ; 2$ to 4 ; and $>4$, via calibrated markings on the wing struts (Mbugua 1996, Ridgway 2010). Survey, environmental, and sighting data were recorded via digital voice recorder and manually transcribed post-flight. Transcription included type of flight leg (transit, transect, cross-leg, or circling), transect number, and specific points of a given transect (begin, end, break off, or resume). Environmental data variables included general weather conditions, visibility, Beaufort sea state, cloud cover, and sun glare. Sighting data transcription included species identification to the lowest taxonomic level possible, reliability of that identification ('definite,' 'probable,' or 'possible'), a count of individuals in the group, an index of the precision of that count ( \pm 1 to \pm 100 , 'at least,' 'number unknown,' or 'no estimate'), the number of calves or juveniles, whether or not photographs were taken, and notes on behaviors. All data were submitted to the NARWC Database, where they underwent an extensive quality assessment/quality control (QA/QC) protocol before archiving.

The aircraft deviated from transects at each E. glacialis sighting so observers could obtain photographs for individual identification (Kraus et al. 1986b), using a Nikon D300 with a $300 \mathrm{~mm} \mathrm{f/2.8} \mathrm{tele-}$ photo lens $(1.4 \times$ teleconverter). Observers attempted to collect oblique photographs of the rostral callosity pattern and other obvious scars or markings, and attempts were made to document each individual within an aggregation. Images were uploaded and processed in the NARWC Catalog (Hamilton et al. 2007), and were compared to other records to identify individuals with assigned catalog numbers. 
The NOAA and CCS aerial surveys for E. glacialis followed protocols similar to those used by the NLPSC, detailed above. These surveys provided comparable sighting, environmental, and photographic data to the NARWC Database and the NARWC Catalog.

\section{Data used in analysis}

Data collected on E. glacialis by many research organizations in the region are submitted to the 2 complementary databases, the NARWC Database and the NARWC Catalog. The Database contains effort and sightings data, and the Catalog houses E. glacialis photographs and accompanying information. In order to supplement data collected within the NLPSC survey area, additional data from a slightly larger area and longer time period were requested from the NARWC Database and Catalog and were used in analyses of behavior and demographics (see 'Data Request Area' in Fig. 1). This area is hereafter referred to as the study area (SA). The time period selected for the additional data request was between 1 January 2010 and 30 June 2015 (the designated NLPSC survey end date).

Three separate datasets were extracted to best support various analyses (Table 1). Dataset 1, including only data collected by the NLPSC, was used for analyses that benefit from the enhanced statistical accuracy afforded by consistent systematic survey effort. Dataset 2 included sightings data submitted to the NARWC Database, and was culled by platform code to reflect only data collected by established research entities and/or data associated with photographs. Dataset 3 included only sightings accompanied by photographs that could be matched to known individuals within the NARWC Catalog. Only data from the NLPSC are included in the 2015 totals for both Datasets 2 and 3, since the NEFSC and CCS data from 2015 had not yet been submitted.

\section{Analyses of spatial and temporal distribution}

To account for variability in sampling effort in comparisons between months, monthly sighting rates were calculated from Dataset 1 as the number of whales sighted divided by amount of effort in $\mathrm{km}$, multiplied by $1000 \mathrm{~km}$ (units are whales per $1000 \mathrm{~km}$ of survey). Effort was defined as the total $\mathrm{km}$ flown including transects, transits, crosslegs, and circling, in sea states up to and including Beaufort 4. Only sightings identified as 'definite' or 'probable' were included. Pooled sighting rate (all survey years combined) was calculated for each month during which E. glacialis were sighted.

An index of annual (1 January to 31 December) sightings per unit effort (SPUE) was calculated to assess annual distribution of E. glacialis in the SA using Dataset 1. The SA was divided into a grid of cells measuring $5 \mathrm{~min}$ of latitude $(9.3 \mathrm{~km})$ by $5 \mathrm{~min}$ of longitude (approximately $7.0 \mathrm{~km}$, narrowing slightly from south to north). Survey transect segments were partitioned into the grid cells, limited to segments at an altitude of $366 \mathrm{~m}$ (1200 ft) or lower, clear visibility to at least $3.7 \mathrm{~km}$ ( $2 \mathrm{n}$ miles), and a sea state up to and including Beaufort 3. All E. glacialis sightings made during those same transect segments were also assigned to the $5^{\prime} \times 5^{\prime}$ cells, limited to definite and probable identifications. The number of whales sighted and total $\mathrm{km}$ of effort were summed within each grid cell by year (2012-2015). SPUE, in whales sighted per $1000 \mathrm{~km}$ of effort, was calculated for each grid cell and mapped in ArcMap v. 10.3.1 (ESRI 2016).

A hot spot analysis was performed, using Dataset 1, to delineate the nature of the clustered distribution of E. glacialis within the SA. ArcMap v. 10.3.1 was used to test for hot spots and cold spots in the SPUE data using the Getis-Ord $G^{*}$ statistic, which identifies statistically significant spatial clusters of high values

Table 1. Dataset definitions and contributors, including the Northeast Large Pelagic Survey Collaborative (NLPSC), Northeast Fisheries Science Center (NEFSC), and Center for Coastal Studies (CCS), with analyses completed. The study area is shown in Fig. 1. NARWC: North Atlantic Right Whale Consortium, NOAA: National Oceanic and Atmospheric Administration, SPUE: sightings per unit effort. Dates are $\mathrm{mm} / \mathrm{dd} / \mathrm{year}$

\begin{tabular}{|llllll|}
\hline \multirow{2}{*}{ Dataset } & Source & Study area & Study period & Contributors & Analyses \\
\hline \multirow{2}{*}{1} & NLPSC Aerial & NLPSC Survey area & $10 / 09 / 2011$ to & NLPSC & $\begin{array}{l}\text { Sighting rates, SPUE, hot } \\
\text { spot, density and abundance } \\
\end{array}$ \\
\cline { 2 - 5 } & Surveys Database & & $06 / 30 / 2015$ & & \\
& NARWC & Data Request Area & $01 / 01 / 2010$ to & NLPSC, NEFSC, & Behavior \\
3 & Sightings Database & & $06 / 30 / 2015$ & CCS, NOAA, other & \\
& NARWC & Data Request Area & $01 / 01 / 2010$ to & NLPSC, NEFSC, & Demographics \\
& Catalog Database & & $06 / 30 / 2015$ & CCS, other & \\
\hline
\end{tabular}


(hot spots) and low values (cold spots) and produces probabilities reflecting statistical confidence levels of 99, 95, 90\%, or not significant. An annual hot spot map was created using combined SPUE data across all survey years, and seasonal hot spot maps were calculated by combining seasonal SPUE data across all years for the 2 seasons in which sightings occurred. In seasonal analyses, winter is defined as December, January, and February, and spring is defined as March, April and May.

In the Getis-Ord $\mathrm{Gi}^{*}$ statistic, the contiguity edges/ corners spatial relationship between cells was used, where cells that share a boundary or corner influence the computations for the target cells. This option is best when polygons are similar in size and distribution, and when spatial interaction increases if the polygons share a boundary. This option is appropriate here, as whales found in one $5^{\prime} \times 5^{\prime}$ cell could easily move into an adjoining cell. The Euclidean distance (straight line) method was used to calculate distances from each cell to neighboring cells.

The Getis-Ord local statistic as defined by ESRI is given as:

$$
G_{i}^{*}=\frac{\sum_{j=1}^{n} W_{i, j} x_{j}-\bar{X} \sum_{j=1}^{n} w_{i, j}}{\sqrt{\frac{\left[n \sum_{j=1}^{n} w_{i, j}^{2}-\left(\sum_{j=1}^{n} w_{i, j}\right)^{2}\right]}{n-1}}}
$$

where $x_{j}$ is the attribute value for feature $j, w_{i, j}$ is the spatial weight between features $i$ and $j, n$ is equal to the total number of features, and:

$$
\begin{gathered}
\bar{X}=\frac{\sum_{j=1}^{n} X_{j}}{n} \\
\mathrm{~S}=\sqrt{\frac{\sum_{j=1}^{n} x_{j}^{2}}{n}-(\bar{X})^{2}}
\end{gathered}
$$

\section{Density and abundance estimations}

Density and abundance estimates were calculated using Dataset 1. The observed distribution of rightangle sighting distances was used in DISTANCE software (Laake et al. 1993, Thomas et al. 2010) to estimate the width of the strip effectively sampled on each side of the transect and its inverse, $f(0)$, the probability density function evaluated at 0 distance. To minimize the variance of the $f(0)$ estimate, an ade- quate sample size is necessary, minimally 25-30 sightings (Buckland et al. 1993), and ideally 40-100 or more (Eberhardt et al. 1979). To reach adequate sample size, all on-transect sightings of large whales with right-angle distance classifications from the surveys were pooled, including E. glacialis, humpback whales Megaptera novaeangliae, fin whales Balaenoptera physalus, sei whales B. borealis, sperm whales Physeter macrocephalus, and unidentified large whales (Jefferson 1996, Barlow 1999). DISTANCE software was then used to fit the observed probability distribution to different statistical models and truncation schemes, selecting the output with the lowest Akaike's information criterion (AIC) score to estimate $f(0)$ and its variance.

An estimate of density $\left(d\right.$, in whales $\left.\mathrm{km}^{-2}\right)$ of E. glacialis was then calculated for each survey transect line by:

$$
d=\frac{n \times g \times f(0)}{2 L}
$$

where $n$ is the number of groups sighted during the transect, $g$ is the average group size for E. glacialis across all sightings during the study, $f(0)$ is the pooled large-whale value output from DISTANCE, and $L$ is the length of the transect. Only sightings meeting the following criteria were included in the estimation: collected during a defined census transect (excludes AOI); Beaufort sea state of 3 or lower; clear visibility of at least $2 \mathrm{n}$ miles; and definite or probable species identification. The variance of the density estimate was calculated additively from the variances of the component parameters:

$$
\operatorname{Var}(d)=\sqrt{\frac{\operatorname{Var}(n)}{n^{2}}+\frac{\operatorname{Var}(g)}{g^{2}}+\frac{\operatorname{Var}[f(0)]}{f(0)^{2}}}
$$

The mean values of $n$ and $g$, and their variances, were computed empirically from the survey data.

The average density for a season-year was calculated as the mean of the individual transect densities, weighted by the transect lengths. Each seasonyear was defined as a 3 mo period within a given survey year (i.e. Spring-2013 = March, April, and May of 2013). The variance of the mean density was similarly calculated as the length-weighted average of the transect variances. Abundance was the weighted mean density times the area surveyed$6910.78 \mathrm{~km}^{2}$ for the season-year periods coinciding with the first 25 surveys or $7789.19 \mathrm{~km}^{2}$ after the RIMA WEA was included. Upper and lower 95\% confidence limits on the abundance estimates were 
calculated from weighted average variance by Student's- $t$ method with the degrees of freedom based on the number of transects flown. Calculated negative values of the lower confidence limit were replaced by 0 .

\section{Behavior}

Analyses of behavior were performed using Dataset 2. Behavioral data associated with sightings were analyzed for spatial and temporal patterns. Recorded behaviors included surface active groups (SAGs), which can be indicative of courtship (Kraus \& Hatch 2001, Parks et al. 2007), and feeding. For these surveys, a SAG was defined as 2 or more whales rolling and touching at the surface. Feeding was only recorded in instances when observers could see an E. glacialis individual swimming open-mouthed at or just below the surface.

\section{Demographics}

Demographics of E. glacialis individuals were analyzed using Dataset 3. Demographics of the individuals identified in the area were compared with demographics of the entire catalogued population presumed to be alive (as of 2015) to assess the age and sex class proportions of the subset of whales using the SA. Individuals not yet matched to known individuals in the NARWC Catalog were not included in analyses. Sex of individuals was based upon NARWC Catalog data from either genetic or visual determinations (Hamilton et al. 2007). Catalog data also provided information on age classes as follows: juvenile (1-8 yr old), adult (at least $9 \mathrm{yr}$ since calf or first sighting), or unknown. Life history data for all individuals that were identified within the SA were obtained from the NARWC Catalog to assess habitat usage.

\section{RESULTS}

In total, 76 systematic aerial surveys were conducted by the NLPSC between October 2011 and June 2015 (Table 2). In addition to this dedicated survey effort in the SA, surveys were also conducted by NEFSC and CCS. Total survey effort by all contributors between January 2010 and June 2015 was $71292 \mathrm{~km}$ (Table 2). With the exception of 2010 and 2011 (the first partial year of NLPSC surveys), the majority of effort $(61803 \mathrm{~km})$ in the SA was con- ducted by the NLPSC. Approximately half of the total systematic survey effort conducted in the SA during 2011 was conducted by the NLPSC, while the other half was conducted by NEFSC.

The total number of Eubalaena glacialis records and data contributors for each database used in analyses varied (Table 3). The NLPSC recorded 60 sightings during the 76 surveys flown during the study period, reflected in Databases 1 and 2. A sighting is a single event in which a whale or whales are observed; therefore, 1 sighting may include 1 or more whales. These 60 sightings contributed to a total of 86 photographed

Table 2. Total annual systematic survey effort within the study area and the contributors, including the Northeast Large Pelagic Survey Collaborative (NLPSC) and others (Northeast Fisheries Science Center and the Center for Coastal Studies)

\begin{tabular}{|lccc|}
\hline \multirow{2}{*}{ Year } & \multicolumn{4}{c}{$\begin{array}{c}\text { Survey effort }(\mathrm{km}) \\
\text { Others }\end{array}$} & Total \\
\cline { 2 - 4 } & NLPSC & 1713 & 1713 \\
2010 & 0 & 3313 & 7499 \\
2011 & 4187 & 1626 & 17479 \\
2012 & 15853 & 769 & 14377 \\
2013 & 13608 & 2068 & 20009 \\
2014 & 17941 & $0^{\text {a }}$ & 10214 \\
2015 & 10214 & 9489 & 71291 \\
Total & 61803 & \multicolumn{3}{l}{} \\
aData from other organizations for 2015 not yet submitted \\
(NLPSC only)
\end{tabular}

Table 3. Contributors for each primary dataset, including National Oceanographic and Atmospheric Administration (NOAA) research vessels, Northeast Fisheries Science Center (NEFSC), the Northeast Large Pelagic Survey Collaborative (NLPSC), and the Center for Coastal Studies (CCS) record type, and number of records for each dataset

\begin{tabular}{|c|c|c|c|}
\hline Dataset & Contributors & Record type & $\begin{array}{l}\text { No. of } \\
\text { records }\end{array}$ \\
\hline 1 & $\begin{array}{l}\text { NLPSC } \\
\text { Total }\end{array}$ & Sightings & $\begin{array}{l}60 \\
60\end{array}$ \\
\hline 2 & $\begin{array}{c}\text { NLSPC } \\
\text { CCS } \\
\text { NOAA / NEFSC } \\
\text { Other } \\
\text { Total }\end{array}$ & Sightings $^{\mathrm{a}}$ & $\begin{array}{r}60 \\
8 \\
32 \\
17 \\
117\end{array}$ \\
\hline 3 & $\begin{array}{l}\text { NLPSC } \\
\text { CCS } \\
\text { NEFSC } \\
\text { Other } \\
\text { Total }\end{array}$ & Individual whales $^{\mathrm{a}}$ & $\begin{array}{r}86 \\
16 \\
167 \\
2 \\
271\end{array}$ \\
\hline \multicolumn{4}{|c|}{$\begin{array}{l}\text { aData from other organizations for } 2015 \text { not yet submittec } \\
\text { (NLPSC only) }\end{array}$} \\
\hline
\end{tabular}


and identified individuals to Database 3. NEFSC collected 32 sightings during the study period. Several of these sightings were of very large groups, which added 167 individual whales to Dataset 3.

\section{Seasonality and distribution}

Sightings of E. glacialis only occurred during the winter and spring, beginning in December and ending in April. Monthly sighting rates (whales per $1000 \mathrm{~km}$ survey effort) across all years were highest in February (6.95) and March (9.04) (Fig. 2).

The distribution of E. glacialis within the SA varied both annually and seasonally. In the years 2012 and 2015, the majority of whales were documented as scattered throughout the northern limits of the SA, while in 2013 and 2014, whales were primarily sighted along the eastern side of the SA (Fig. 3). The hot spot analysis highlighted areas of seasonally consistent E. glacialis aggregations (Fig. 4). In the winter season, distribution shifted offshore, and hot spots appeared to the north and east of the MA WEA. In the spring, whales tended to be distributed closer to shore, and the largest hot spot was located in the northwestern corner of the RIMA WEA. When viewed cumulatively over all years, hot spots were located in the northwestern part of the SA and to the east, due south of Nantucket Island.

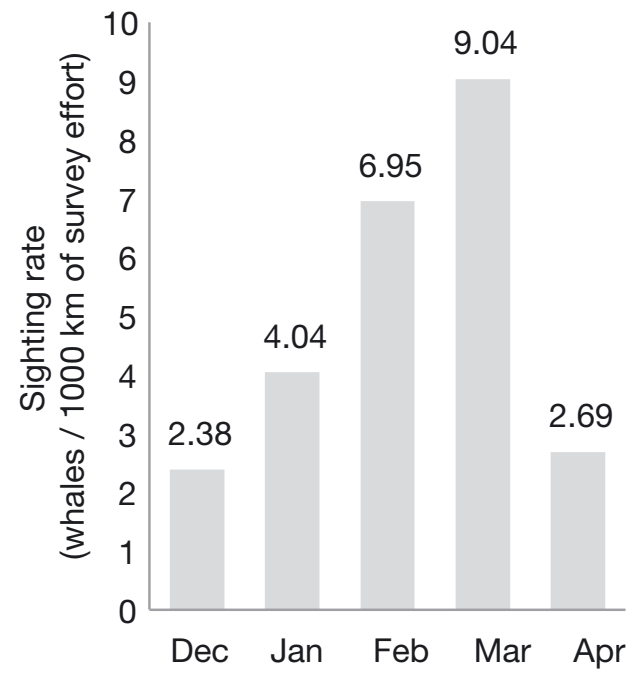

Fig. 2. Monthly sighting rates of North Atlantic right whales Eubalaena glacialis in the Northeast Large Pelagic Survey Collaborative (NLPSC) study area. Units are whales sighted per $1000 \mathrm{~km}$ of survey effort across all years of the study period (2011-2015) from Dataset 1, which included only data collected by the NLPSC. Sighting rates for May through November were all 0s

\section{Density and abundance}

Seasonal abundance point estimates during winter and spring ranged from 0 in the winter of 2012 to a high of 35 in the winter of 2013 (Table 4). Abundance generally tended to be higher in spring than in winter, with the exception of 2013 . The $95 \%$ confidence limits for these estimates were typically wide, with the upper confidence limit ranging up to 296. The abundance estimates are not corrected for whales below the surface not sighted during aerial surveys.

\section{Behavior}

On 52 occasions feeding or SAG behaviors were recorded, and the remaining 65 sightings were categorized as none/other (Fig. 5). Feeding behavior was recorded for 39 (33\%) of the sightings. Feeding was seen in all years of the study period (2010-2015), and exclusively during the months of March and April. There were 13 instances of SAG behavior recorded, involving a total count of 61 whales. The average SAG group size was 4.7 whales, with a range of 2 to 14 whales. This behavior occurred during all years (2010-2015), with the exception of 2011, and was primarily observed during the month of March.

\section{Population demographics}

Dataset 3 contained 271 records of 196 identified individuals. Of these 196 individuals, 32 (16\%) were documented only in the SA and not in any other known habitat during the January 2010 to June 2015 period. An average of 35 individual whales was identified in the SA annually. Of the 196 photodocumented individuals, $35 \%(\mathrm{n}=68)$ were females, $58 \%(\mathrm{n}=114)$ were males, and the remainder $(\mathrm{n}=$ 14) were of unknown sex. Of the 188 individuals that had assigned age classes, $64 \%$ were adults and $32 \%$ were juveniles. Six individuals were classified as calves at their time of sighting in the SA. The average age of individuals identified in the SA was $10.8 \mathrm{yr}$

There were 34 different reproductive female ('cows') identified in the SA. For 8 of these cows, the only documented record since the start of 2010 was in the SA. Cows sighted varied in reproductive age (first-time mother to $26 \mathrm{yr}$ since first calving) and number of calves born $\left(1-7_{i}\right)$. The majority of cow sightings occurred during the month of April. Of the cows that 

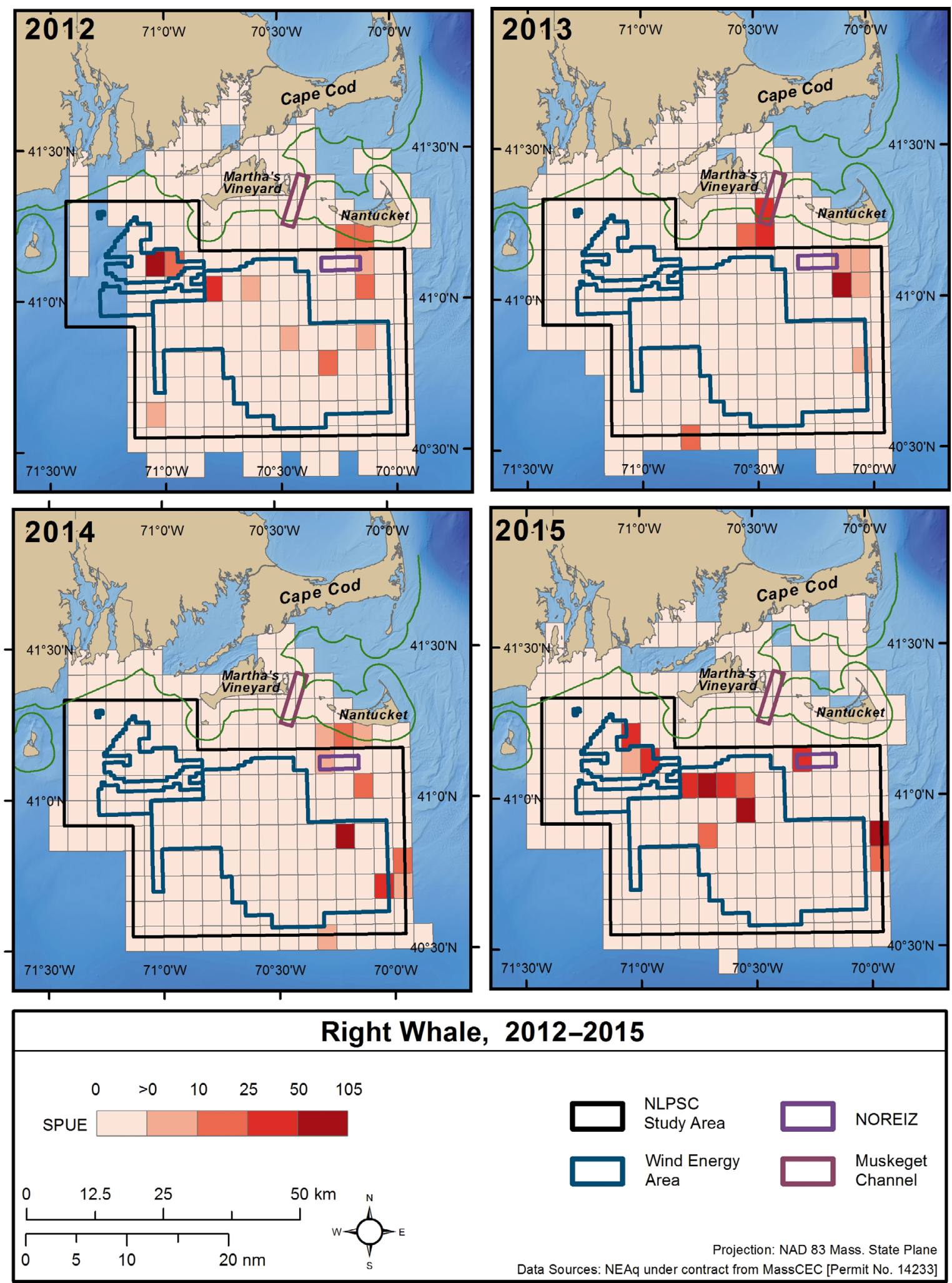

Fig. 3. Sightings per unit effort (SPUE) of North Atlantic right whales Eubalaena glacialis per 1000 km in the Northeast Large Pelagic Study Collaborative (NLPSC) study area, partitioned annually (2012-2015) from Dataset 1, which included only data collected by the NLPSC. Other abbreviations and additional details of the study area are shown in Fig. 1. SPUE values are number of animals sighted per $1000 \mathrm{~km}$ of survey track summarized by $5^{\prime} \times 5^{\prime}$ grid cells 

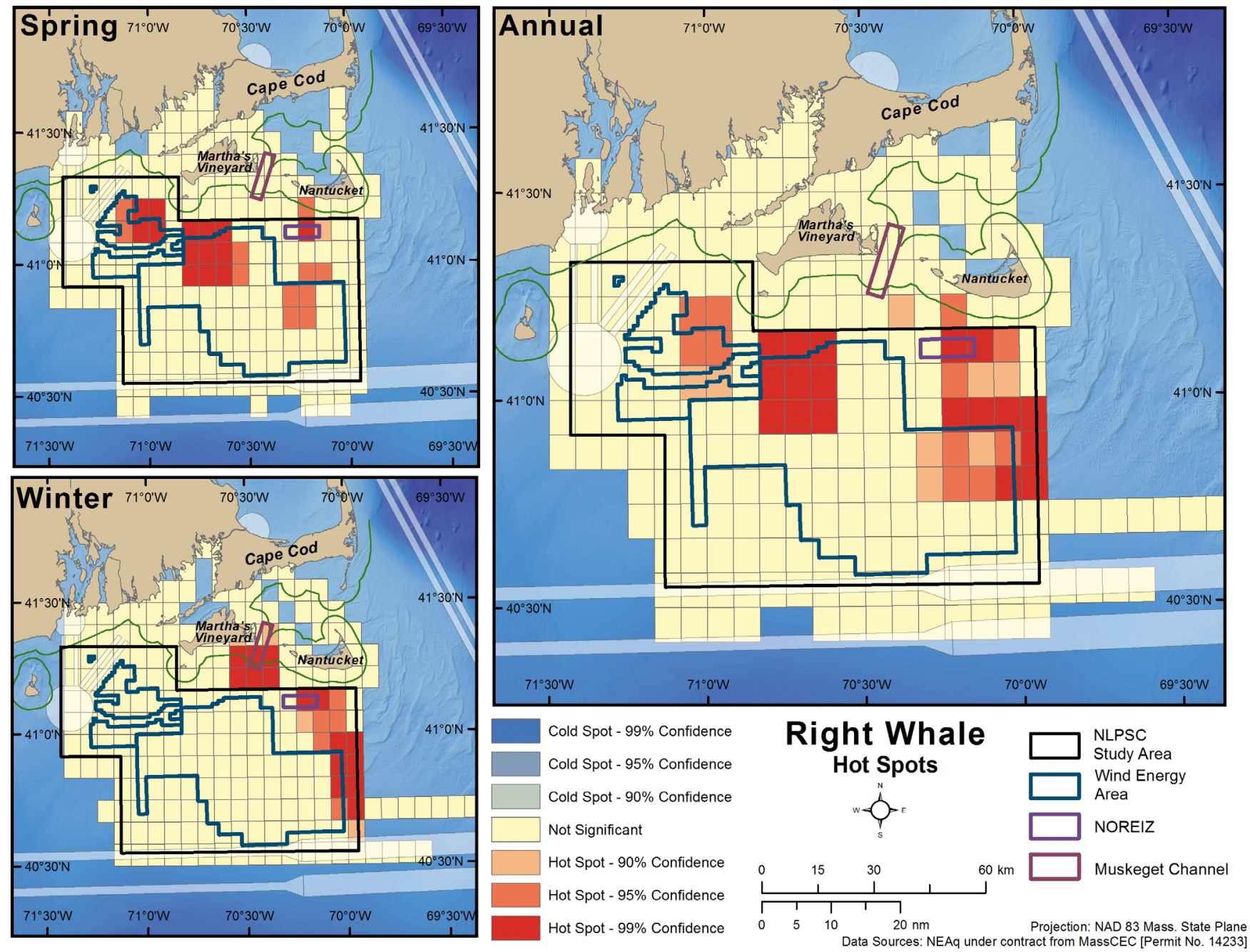

Fig. 4. Hot spot analysis of North Atlantic right whale Eubalaena glacialis distribution in the Northeast Large Pelagic Survey Collaborative (NLPSC) study area partitioned by season (spring and winter) and overall (2011-2015) from Dataset 1, which included only data collected by the NLPSC. No sightings were recorded in summer or autumn. Existing shipping lanes are depicted by light blue and light yellow areas. Other abbreviations and additional details of the study area are shown in Fig. 1.

Distance scale bar applies to 'annual' map

Table 4. Winter and spring density and abundance estimates of North Atlantic right whales Eubalaena glacialis in the Northeast Large Pelagic Survey Collaborative (NLPSC) study area by season and year for all years of the study period (2011-2015) from Dataset 1 (see Table 1). All summer and fall estimates were 0

\begin{tabular}{|c|c|c|c|c|c|c|c|}
\hline $\begin{array}{l}\text { Season \& } \\
\text { year }\end{array}$ & $\begin{array}{l}\text { No. of } \\
\text { transects } \\
\text { flown }\end{array}$ & $\begin{array}{l}\text { On-effort } \\
\text { distance } \\
\text { flown }(\mathrm{km})\end{array}$ & $\begin{array}{c}\text { No. of } \\
\text { groups, } \\
\text { individuals }\end{array}$ & $\begin{array}{c}\text { Density } \\
\text { (ind. } \mathrm{km}^{-2} \text { ) }\end{array}$ & $\begin{array}{c}\text { Variance of } \\
\text { density }\end{array}$ & $\begin{array}{l}\text { Uncorrected } \\
\text { abundance }\end{array}$ & $\begin{array}{l}95 \% \\
\text { confidence } \\
\text { limits }\end{array}$ \\
\hline Winter 2012 & 30 & 1889.7 & 0,0 & 0 & - & 0 & - \\
\hline Spring 2012 & 56 & 2866.4 & 8,13 & 0.0035 & 0.0027 & 24 & 0,118 \\
\hline Winter 2013 & 16 & 845.0 & 3,5 & 0.0045 & 0.0040 & 35 & 0,296 \\
\hline Spring 2013 & 39 & 2521.6 & 1,1 & 0.0005 & 0.0003 & 4 & 0,43 \\
\hline Winter 2014 & 26 & 1500.6 & 1,3 & 0.0008 & 0.0006 & 7 & 0,83 \\
\hline Spring 2014 & 41 & 2616.0 & 4,11 & 0.0019 & 0.0016 & 15 & 0,109 \\
\hline Winter 2015 & 28 & 1847.5 & 4,15 & 0.0027 & 0.0020 & 21 & 0,155 \\
\hline Spring 2015 & 65 & 4275.8 & 10,44 & 0.0029 & 0.0021 & 23 & 0,111 \\
\hline
\end{tabular}


visited the SA, 11 (32\%) visited in more than 1 year. Six of the cows sighted in the SA were seen with calves, and the majority of these cow/calf sightings occurred in 2010 and 2011.

\section{DISCUSSION}

These surveys represent the most intensive systematic aerial survey effort executed within the SA to date, and they revealed an annually consistent winter and spring occurrence of Eubalaena glacialis. Within the SA, E. glacialis appear to arrive in Decem-

Table 5. North Atlantic right whale Eubalaena glacialis cows observed in the study area between January 2010 and June 2015. EGNo is the ID number of the whale in the North Atlantic Right Whale Consortium (NARWC) Catalog. Month-year entries in bold identify occurrences where the individual was accompanied by a calf

\begin{tabular}{|c|c|c|c|}
\hline EGNo & $\begin{array}{l}\text { Visits to study area } \\
\text { (Month, year) }\end{array}$ & $\begin{array}{l}\text { Reproductive } \\
\text { span (yr) }\end{array}$ & $\begin{array}{c}\text { Total calves } \\
\text { born }\end{array}$ \\
\hline 1012 & Mar 2011 & 26 & 7 \\
\hline 1123 & Apr 2011 & 20 & 5 \\
\hline 1151 & Apr 2010, Apr 2011 & 22 & 6 \\
\hline 1608 & Apr 2010, Feb 2013 & 6 & 2 \\
\hline 1611 & Feb 2011 & 8 & 3 \\
\hline 1612 & Apr 2011 & 27 & 6 \\
\hline 1970 & Mar 2012, Apr 2014 & 13 & 4 \\
\hline 2029 & Apr 2010 & 8 & 3 \\
\hline 2145 & Apr 2010 & 8 & 4 \\
\hline 2223 & Mar 2012 & 4 & 2 \\
\hline 2320 & Apr 2010 & 7 & 3 \\
\hline 2330 & Apr 2010 & 9 & 3 \\
\hline 2503 & Feb 2013 & 8 & 3 \\
\hline 2605 & Apr 2012, Feb 2013 & 3 & 2 \\
\hline 2642 & Apr 2014, Mar 2015 & 3 & 2 \\
\hline 2746 & Apr 2010 & 7 & 3 \\
\hline 2753 & Apr 2010 & 5 & 2 \\
\hline 2791 & Apr 2010, Apr 2011 & 3 & 2 \\
\hline 2912 & Apr 2011, Apr 2013 & 6 & 2 \\
\hline 3010 & Apr 2010, Apr 2011 & 6 & 2 \\
\hline 3020 & Mar 2015 & 3 & 2 \\
\hline 3101 & Feb 2013 & 0 & 1 \\
\hline 3108 & April 2010 & 0 & 1 \\
\hline 3115 & Apr 2011, Mar 2014 & 3 & 2 \\
\hline 3123 & Apr 2010 & 0 & 1 \\
\hline 3130 & Apr 2011, Mar 2014 & 3 & 2 \\
\hline 3142 & Apr 2010 & 0 & 1 \\
\hline 3280 & Apr 2010 & 0 & 1 \\
\hline 3317 & Apr 2014 & 0 & 1 \\
\hline 3320 & Mar 2015 & 0 & 1 \\
\hline 3420 & Apr 2010 & 0 & 1 \\
\hline 3513 & Apr 2013 & 0 & 1 \\
\hline 3520 & Mar 2015 & 0 & 1 \\
\hline 3546 & Apr 2010, Apr 2011 & 0 & 1 \\
\hline 3692 & Apr 2010 & 0 & 1 \\
\hline
\end{tabular}

ber and leave in May, and this seasonal presence is consistent with historical records (Reeves et al. 1978, CETAP 1982, Kenney \& Vigness-Raposa 2010). Although no visual detections of E. glacialis were made in the SA during the month of June, the occurrence of E. glacialis in nearby habitats (the Great South Channel, $<100 \mathrm{~km}$ east of the SA) is high during that month (Kenney et al. 1995, Brillant et al. 2015). Acoustic detections of E. glacialis were made in the month of June during concurrent acoustic surveys of the SA (Kraus et al. 2016). E. glacialis were observed using the northern portion of the WEAs as a spring habitat and exhibited skim-feeding behavior there. They also used the areas directly adjacent to the north and east of the WEAs as a winter habitat, although skim feeding was not observed there.

Behavioral observations help define the characteristics and importance of a habitat to any species. E. glacialis were recorded feeding and engaging in SAGs, with observations of feeding behavior occurring exclusively during spring. Since E. glacialis can only forage successfully in areas of dense copepod aggregations (Kenney et al. 1986, Kenney \& Wishner 1995), observations of feeding suggest concentrations of zooplankton are present, although prey species could not be confirmed without oceanographic sampling in the area. Sub-surface feeding at depths beyond visibility to observers, which occurs more often than skim-feeding behavior, could not be confirmed in the SA (Mayo \& Marx 1990, Kenney \& Wishner 1995, Baumgartner \& Mate 2003, Baumgartner et al. 2003). However, the lack of uniformity in distribution depicted by the annual SPUE analysis (Fig. 3) and hot spot analysis (Fig. 4), and the apparent presence of high-density zooplankton concentrations in the area, may indicate sub-surface feeding. Whales feeding at depth within the habitat could reduce aerial survey detection rates, as feeding dives can last for up to $20 \mathrm{~min}$ (Winn et al. 1995). The regular observations of SAGs, observed in all but 1 year, may indicate that animals are mating in this habitat, although mating does not always occur in SAGs (Kraus \& Hatch 2001, Parks et al. 2007).

When compared with the latest 'best estimate' of 526 individuals (Pettis \& Hamilton 2015), the subset of E. glacialis photo-identified in the SA $(\mathrm{n}=196)$ constitutes $37 \%$ of this photographically-based total. The average number of individuals $(n=35)$ photoidentified in the SA per year was comparable to the combined winter and spring abundance estimates (between 24 and 44). However, counts of individual E. glacialis through photoidentification capture only those whales that are sighted and photographed. 

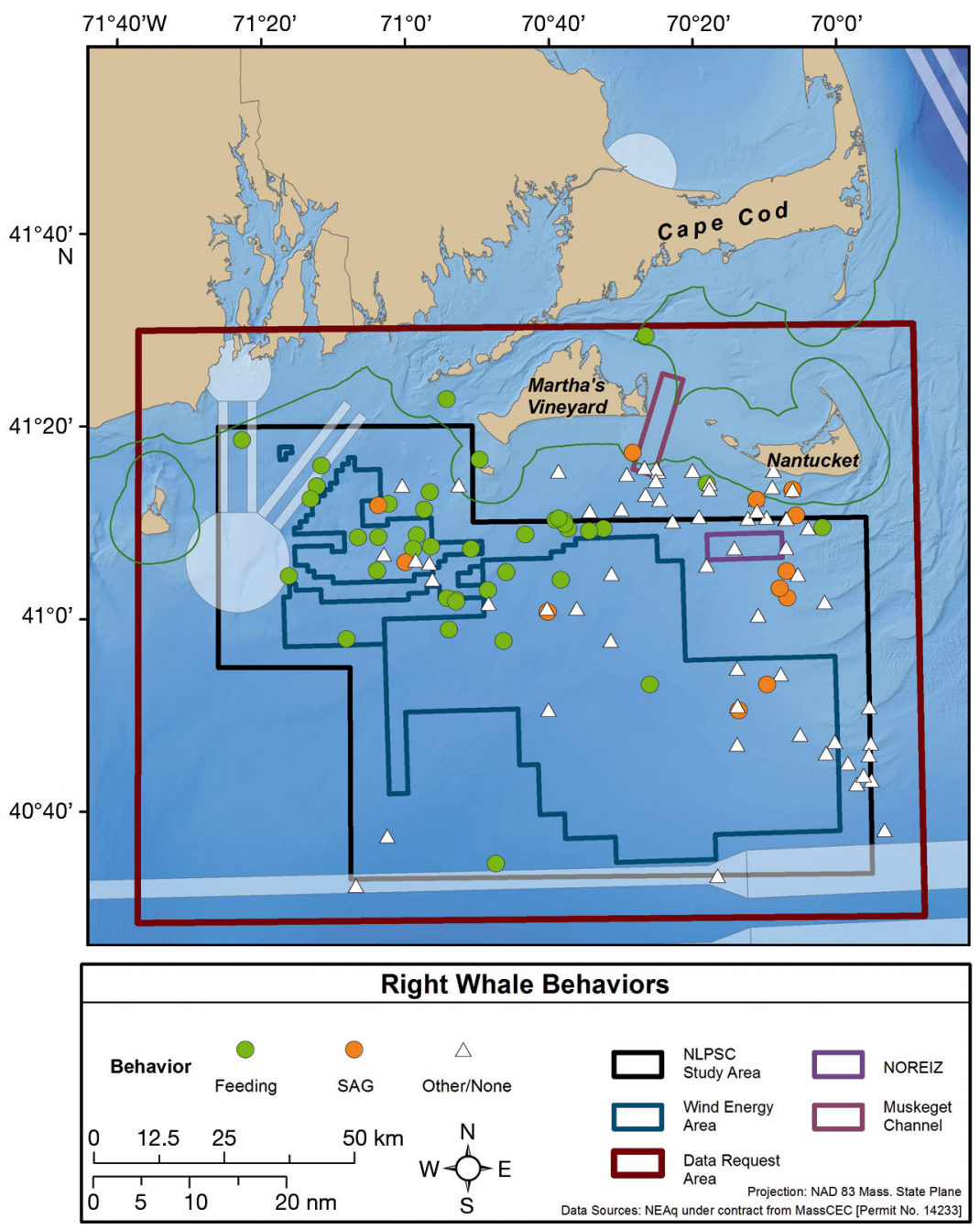

Fig. 5. Locations of North Atlantic right whale Eubalaena glacialis behaviors recorded for sightings (1 or more whales) in the Data Request Area (see Fig. 1) between 1 January 2010 and 30 June 2015 from Dataset 2 (see Table 1). Behaviors are categorized as feeding, surface active group (SAG), or none/other. Existing shipping lanes are depicted in light blue. Other abbreviations and additional details of the study area are shown in Fig. 1

Likewise, the abundance estimates provided here are based only on those animals at the surface, have wide confidence intervals, and are limited by sample size and effort (Marsh \& Sinclair 1989). Survey effort was limited to 2 surveys $\mathrm{mo}^{-1}$, and not all months of all years in the study period were documented. Therefore, it is likely that some individuals were missed, and that both the photographic counts and the abundance estimates represent the minimum number of E. glacialis in the area.

Every demographic class of E. glacialis has been documented within the SA since the start of 2010. The sex ratio of E. glacialis documented in the NARWC Catalog is $39 \%$ females and $55 \%$ males
(North Atlantic Right Whale Consortium 2015), which is comparable to the sex ratio of individuals documented in the SA (35\% female, $58 \%$ male). The number of cows that were sighted here since 2010 constitutes $30 \%$ of the 115 known (alive) cows in the population (North Atlantic Right Whale Consortium 2015). Sightings of cows without calves in the SA were particularly valuable, as the opportunity to document cows in years when they do not have calves is rare (Brown et al. 2001). Documentation of these females greatly improves population monitoring, since the apparent loss of even 1 cow can have negative population recovery consequences (Fujiwara \& Caswell 2001).

Ongoing monitoring of this E. glacialis habitat will be important in informing habitat use patterns, particularly with recent shifts in habitat use that have occurred elsewhere, and in other seasons (Cole et al. 2013, Khan et al. 2014). Combined visual and acoustic monitoring of E. glacialis can better characterize their occurrence (Morano et al. 2012), particularly when aerial surveys are not possible (Clark et al. 2010). In this study, concurrent acoustic monitoring by the Cornell University Lab of Ornithology revealed a longer period of occurrence than the shorter seasonal period that was detected by aerial surveys (Kraus et al. 2016). Recent studies of $E$. glacialis distribution in coastal areas that used a combination of acoustic and visual assessment techniques found that aerial surveys were useful for estimating abundance and identifying individuals, but that acoustic monitoring detected occurrence over longer periods of time (Whitt et al. 2013, Hodge et al. 2015, Oedekoven et al. 2015).

A variety of offshore industrial activities underway or proposed off the eastern coast of North America are likely to contribute to the ongoing alteration of E. glacialis habitats, potentially adding stressors to a species already under threat from fishing and shipping (Kraus \& Rolland 2007). Underwater noise from some wind energy facility construction or operation activities in this region may require mitigation, as 
E. glacialis communicate less in the presence of elevated sound levels, and physiological stress is increased (Hatch et al. 2012, Rolland et al. 2012). Increased stress levels may contribute to reduced fecundity, suppressed immunity and reduced reproductive rates (Rolland et al. 2007). A recent analysis demonstrated a decline in overall health in all E. glacialis individuals over the last $30 \mathrm{yr}$, possibly the result of cumulative stressors (Rolland et al. 2016). However, there may also be positive effects from the operational phase of wind energy facilities, including the possible exclusion of fisheries from areas frequented by E. glacialis, with an associated reduction in entanglement risk (Bergström et al. 2014). In response to vessel strikes and stress created by shipping noise, seasonal management areas (SMAs) have been implemented by NMFS to slow ships and alert mariners and fishermen to E. glacialis occurrence in portions of their range during distinct seasonal periods. The current shipping lanes that exist within the SA are depicted in light blue in Fig. 1. Since there is an annually and seasonally consistent use of this habitat, an SMA could provide E. glacialis protection from ship strikes and potentially other anthropogenic activities (Van der Hoop et al. 2013, 2015).

Mitigation options for wind energy facility installations have been identified and used in other regions (IWC 2012), and our study provides important findings to support development and refinement of such measures in this area. For example, construction activities that may have harmful impacts could be scheduled outside the seasonal presence of E. glacialis in the WEAs. Additionally, the E. glacialis distribution patterns shown here can be used to dictate the timing and location of some activities. The 'Right Whale Exclusion Zone' for the RIMA WEA currently proposed by BOEM in Alternative B (BOEM 2013) overlaps with areas of high E. glacialis occurrence identified in the hot spot analysis, and could be further adapted to reflect these findings. Similarly, the exclusion zone currently proposed in the MA WEA (BOEM 2014) can be updated with the findings in this study. Areas of lowest E. glacialis use appear to be in the southern portion of the MA WEA lease blocks, which may indicate that development in these areas would have less impact on the species.

In conclusion, this area appears to be a seasonally important habitat for E. glacialis, and combined visual and acoustic monitoring as well as management actions and mitigation strategies can be applied to ensure minimal impacts. Recent evidence that factors like fisheries interactions and declining overall health are negatively affecting the E. glacialis population (Knowlton et al. 2012, Rolland et al. 2016), combined with a lack of available data on the impacts of wind energy development on the species, call for cautious and comprehensive measures to provide protection. The long-term impacts of wind farm construction and placement on large whales are unknown; therefore, the first facilities placed in large whale habitat will offer an opportunity to test their effects. The baseline data collected in these WEAs can be combined with well-known life history information to assess impacts on the E. glacialis population, and this may inform appropriate strategies for future wind energy development in other known E. glacialis or large whale habitats.

Acknowledgements. NLPSC aerial surveys were conducted under NOAA Permit 14233, issued to S.D.K. The MassCEC and BOEM supported this study under Cooperative Agreement number M12AC00. Scientists and observers who participated in this work include J. Taylor, T. Montgomery, O. O'Brien, M. Hagbloom, R. Lynch, and L. Crowe. We thank them for their contributions to data collection and data processing. We are grateful to our collaborators at the Cornell Lab of Ornithology, including C. Clark, A. Rice, B. Estabrook, and J. Tielens. This work includes additional data collected by aerial surveys conducted by the NEFSC, and we specifically acknowledge the work of A. Henry, C. Khan, J. Gatzke, and P. Duley. We also recognize additional collaborators from the CCS, including L. Ganley and P. Hughes. These surveys would not have been possible without the extraordinary efforts of EnviroEye LLC (formerly ASSIST Aviation Solutions LLC), particularly pilots Aiden SeltsamWilps, Keith Lapierre, Don Turner, and Dan Fields. We acknowledge the cheerful and knowledgeable support of P. Hamilton and H. Pettis for their help with the NARWC Catalog.

\section{LITERATURE CITED}

Bailey H, Brookes KL, Thompson PM (2014) Assessing environmental impacts of offshore wind farms: lessons learned and recommendations for the future. Aquat Biosyst 10:8

Barlow J (1999) Trackline detection probability for longdiving whales. In: Garner GW, Amstrup SC, Laake JL, Manly BFJ, McDonald LL, Robertson DG (eds) Marine mammal survey and assessment methods. Balkema, Rotterdam, p 209-221

* Baumgartner MF, Mate BR (2003) Summertime foraging ecology of North Atlantic right whales. Mar Ecol Prog Ser 264:123-135

Baumgartner MF, Cole TVN, Campbell RG, Teegarden GJ, Durbin EG (2003) Associations between North Atlantic right whales and their prey, Calanus finmarchicus, over diel and tidal time scales. Mar Ecol Prog Ser 264:155-166

Bergström L, Kautsky L, Malm T, Rosenberg R, Wahlberg M, Capetillo NÅ, Wilhelmsson D (2014) Effects of offshore wind farms on marine wildlife - a generalized impact assessment. Environ Res Lett 9:034012 
BOEM (Bureau of Ocean Energy Management) (2013) Commercial wind lease issuance and site assessment activities on the Atlantic outer continental shelf offshore Rhode Island and Massachusetts. Revised environmental assessment, OCS EIS/EA BOEM 2013-1131. BOEM, Washington, DC

BOEM (2014) Commercial wind lease issuance and site assessment activities on the Atlantic outer continental shelf offshore Massachusetts. Revised environmental assessment, OCS EIS/EA BOEM 2014-603. BOEM, Washington, DC

Brillant SW, Vanderlaan ASM, Rangeley RW, Taggart CT (2015) Quantitative estimates of the movement and distribution of North Atlantic right whales along the northeast coast of North America. Endang Species Res 27: 141-154

Brown MW, Brault S, Hamilton PK, Kenney RD and others (2001) Sighting heterogeneity of right whales in the western North Atlantic: 1980-1992. J Cetacean Res Manag Spec Issue 2:245-250

Brown MW, Kraus SD, Slay CK, Garrison LP (2007) Surveying for science, discovery, and management. In: Kraus SD, Rolland RM (eds) The urban whale: North Atlantic right whales at the crossroads. Harvard University Press, Cambridge, MA, p 105-137

Buckland ST, Anderson DR, Burnham KP, Laake JL (1993) Distance sampling: estimating abundance of biological populations. Chapman and Hall, London

Carstensen J, Henriksen OD, Teilmann J (2006) Impacts of offshore wind farm construction on harbour porpoises: acoustic monitoring of echolocation activity using porpoise detectors (T-PODs). Mar Ecol Prog Ser 321:295-308

CETAP (Cetacean and Turtle Assessment Program) (1982) A characterization of marine mammals and turtles in the Mid- and North Atlantic areas of the U.S. Outer Continental Shelf. Final report, contract AA551-CT8-48, for the US Bureau of Land Management, Washington, DC. CETAP, University of Rhode Island, Kingston, RI

Clark CW, Gillespie D, Nowacek DP, Parks SE (2007) Listening to their world: acoustics for monitoring and protecting right whales in the urbanized ocean. In: Kraus SD, Rolland RM (eds) The urban whale: North Atlantic right whales at the crossroads. Harvard University Press, Cambridge, MA, p 333-357

Clark CW, Ellison WT, Southall BL, Hatch L, Van Parijs SM, Frankel A, Ponirakis D (2009) Acoustic masking in marine ecosystems: intuitions, analysis, and implication. Mar Ecol Prog Ser 395:201-222

Clark CW, Brown MW, Corkeron P (2010) Visual and acoustic surveys for North Atlantic right whales, Eubalaena glacialis, in Cape Cod Bay, Massachusetts, 20012005: management implications. Mar Mamm Sci 26: 837-854

Cole TVN, Stimpert A, Pomfret L, Houle K, Niemeyer M (2007) North Atlantic Right Whale Sighting Survey (NARWSS) and Right Whale Sighting Advisory System (RWSAS) 2002 results summary. NEFSC Ref Doc 07-18a. NMFS, Woods Hole, MA

Cole TVN, Hamilton P, Henry AG, Duley P, Pace RM III, White BN, Frasier T (2013) Evidence of a North Atlantic right whale Eubalaena glacialis mating ground. Endang Species Res 21:55-64

Doucette GJ, Mikulski CM, King KL, Roth PB and others (2012) Endangered North Atlantic right whales (Eubalaena glacialis) experience repeated, concurrent expo- sure to multiple environmental neurotoxins produced by marine algae. Environ Res 112:67-76

Eberhardt LL, Chapman DG, Gilbert JR (1979) A review of marine mammal census methods. Wildl Monogr 63:1-46

ESRI (Environmental Systems Research Institute) (2016) ArcGIS Desktop: release 10.3.1. ESRI, Redlands, CA

Fortune SME, Trites AW, Mayo CA, Rosen DAS, Hamilton PK (2013) Energetic requirements of North Atlantic right whales and the implications for species recovery. Mar Ecol Prog Ser 478:253-272

Fujiwara M, Caswell H (2001) Demography of the endangered North Atlantic right whale. Nature 414:537-541

Hamilton PK, Mayo CA (1990) Population characteristics of right whales (Eubalaena glacialis) observed in Cape Cod and Massachusetts Bays, 1978-1986. Rep Int Whaling Comm Spec Issue 12:203-208

Hamilton PK, Knowlton AR, Marx MK (2007) Right whales tell their own stories: the photo-identification catalog. In: Kraus SD, Rolland RM (eds) The urban whale: North Atlantic right whales at the crossroads. Harvard University Press, Cambridge, MA, p 75-104

*Hatch LT, Clark CW, Van Parijs SM, Frankel AS, Ponirakis DW (2012) Quantifying loss of acoustic communication space for right whales in and around a US National Marine Sanctuary. Conserv Biol 26:983-994

* Hodge KB, Muirhead CA, Morano JL, Clark CW, Rice AN (2015) North Atlantic right whale occurrence near wind energy areas along the mid-Atlantic US coast: implications for management. Endang Species Res 28:225-234

IWC (International Whaling Commission) (2012) Report of the Workshop on Interactions between Marine Renewable Projects and Cetaceans Worldwide. IWC Scientific Committee meeting paper SC/64/Rep6. IWC, Cambridge

Jacobsen KO, Marx M, Øien N (2004) Two-way transAtlantic migration of a North Atlantic right whale (Eubalaena glacialis). Mar Mamm Sci 20:161-166

Jefferson TA (1996) Estimates of abundance of cetaceans in offshore waters of the northwestern Gulf of Mexico, 1992-1993. Southwest Nat 41:279-287

Kenney RD (2011) The North Atlantic Right Whale Consortium Database: a guide for users and contributors, revised edition. North Atlantic Right Whale Consortium Ref Doc 2011-01. University of Rhode Island, Narragansett, RI

Kenney RD, Vigness-Raposa KJ (2010) Marine mammals and sea turtles of Narragansett Bay, Block Island Sound, Rhode Island Sound, and nearby waters: an analysis of existing data for the Rhode Island Ocean Special Area Management Plan. In: Ocean SAMP, Vol 2. Rhode Island Coastal Resources Management Council, Wakefield, RI

Kenney RD, Wishner KF (1995) The South Channel Ocean Productivity EXperiment. Cont Shelf Res 15:373-384

*Kenney RD, Hyman AM, Owen RE, Scott GP, Winn HE (1986) Estimation of prey densities required by western North Atlantic right whales. Mar Mamm Sci 2:1-13

Kenney RD, Winn HE, Macaulay MC (1995) Cetaceans in the Great South Channel, 1979-1989: right whale (Eubalaena glacialis). Cont Shelf Res 15:385-414

Khan C, Duley P, Henry A, Gatzke J, Cole T (2014) North Atlantic Right Whale Sighting Survey (NARWSS) and Right Whale Sighting Advisory System (RWSAS) 2013 results summary. NEFSC Ref Doc 14-11. NMFS, Woods Hole, MA

Knowlton AR, Brown MW (2007) Running the gauntlet: right whales and vessel strikes. In: Kraus SD, Rolland RM (eds) The urban whale: North Atlantic right whales at the 
crossroads. Harvard University Press, Cambridge, MA, p 409-435

Knowlton AR, Kraus SD (2001) Mortality and serious injury of northern right whales (Eubalaena glacialis) in the western North Atlantic Ocean. J Cetacean Res Manag Spec Issue 2:193-208

Knowlton AR, Sigurjónsson J, Ciano JN, Kraus SD (1992) Long-distance movements of North Atlantic right whales (Eubalaena glacialis). Mar Mamm Sci 8:397-405

Knowlton AR, Hamilton PK, Marx MK, Pettis HM, Kraus SD (2012) Monitoring North Atlantic right whale Eubalaena glacialis entanglement rates: a $30 \mathrm{yr}$ retrospective. Mar Ecol Prog Ser 466:293-302

Kraus SD, Hatch JJ (2001) Mating strategies in the North Atlantic right whale (Eubalaena glacialis). J Cetacean Res Manag Spec Issue 2:237-244

Kraus SD, Rolland RM (2007) The urban whale syndrome. In: Kraus SD, Rolland RM (eds) The urban whale: North Atlantic right whales at the crossroads. Harvard University Press, Cambridge, MA, p 488-513

Kraus SD, Prescott JH, Turnbull PV, Reeves RR (1982) Preliminary notes on the occurrence of the North Atlantic right whale (Eubalaena glacialis) in the Bay of Fundy. Rep Int Whaling Comm 32:407-411

Kraus SD, Prescott JH, Knowlton AR, Stone GS (1986a) Migration and calving of right whales (Eubalaena glacialis) in the western North Atlantic. Rep Int Whaling Comm Spec Issue 10:139-144

Kraus SD, Moore KW, Price CW, Crone MJ, Watkins WA, Winn HE, Prescott JH (1986b) The use of photographs to identify individual North Atlantic right whales (Eubalaena glacialis). Rep Int Whaling Comm Spec Issue 10: 145-151

Kraus SD, Brown MW, Caswell H, Clark CW and others (2005) North Atlantic right whales in crisis. Science 309: 561-562

Kraus SD, Leiter S, Stone K, Wikgren B and others (2016) Northeast large pelagic survey collaborative aerial and acoustic surveys for large whales and sea turtles. OCS Study BOEM 2016-054. US Department of the Interior, Bureau of Ocean Energy Management, Sterling, VA. https://www.boem.gov/RI-MA-Whales-Turtles/

Laake JL, Buckland ST, Anderson DR, Burnham KP (1993) DISTANCE user's guide V2.0. Colorado Cooperative Fish and Wildlife Research Unit, Colorado State University, Fort Collins, CO

* Madsen PT, Wahlberg M, Tougaard J, Lucke K, Tyack P (2006) Wind turbine underwater noise and marine mammals: implications of current knowledge and data needs. Mar Ecol Prog Ser 309:279-295

Marsh H, Sinclair DF (1989) Correcting for visibility bias in strip transect aerial surveys of aquatic fauna. J Wildl Manag 53:1017-1024

Mayo CA, Marx MK (1990) Surface foraging behavior of the North Atlantic right whale and associated plankton characteristics. Can J Zool 68:2214-2220

Mbugua S (1996) Counting elephants from the air — sample counts. In: Kangwana K (ed) Studying elephants. Technical handbook no. 7. African Wildlife Federation, Nairobi

Morano JL, Rice AN, Tielens JT, Estabrook BJ, Murray A, Roberts BL, Clark CW (2012) Acoustically detected yearround presence of right whales in an urbanized migration corridor. Conserv Biol 26:698-707

Nedwell J, Howell D (2004) A review of offshore windfarm related underwater noise sources. Tech Rep 544R0308.
Prepared for COWRIE. Subacoustech Ltd., Hampshire Nichols OC, Kenney RD, Brown MW (2008) Spatial and temporal distribution of North Atlantic right whales (Eubalaena glacialis) in Cape Cod Bay, USA, and implications for management. Fish Bull 108:270-280

NMFS (National Marine Fisheries Service) (1994) Designated critical habitat; northern right whale. Fed Regist 59:28793-28808

NOAA (National Oceanic and Atmospheric Administration) (2016) Endangered and threatened species; critical habitat for endangered North Atlantic right whale. Fed Regist 81:4838-4874

North Atlantic Right Whale Consortium (2015) North Atlantic Right Whale Consortium Identification Database 10/27/2016. New England Aquarium, Boston, MA

Oedekoven C, Fleishman E, Hamilton P, Clark JS, Schick RS (2015) Expert elicitation of seasonal abundance of North Atlantic right whales Eubalaena glacialis in the midAtlantic. Endang Species Res 29:51-58

* Parks SE, Ketten DR, O'Malley JT, Arruda J (2007) Anatomical predictions of hearing in the North Atlantic right whale. Anat Rec 290:734-744

* Parks SE, Johnson M, Nowacek D, Tyack PL (2011) Individual right whales call louder in increased environmental noise. Biol Lett 7:33-35

Patrician MR, Biedron IS, Esch HC, Wenzel FW and others (2009) Evidence of a North Atlantic right whale calf (Eubalaena glacialis) born in northeastern U.S. waters. Mar Mamm Sci 25:462-477

Pettis HM, Hamilton PK (2015) North Atlantic Right Whale Consortium 2015 annual report card. North Atlantic Right Whale Consortium, Boston, MA

Reeves RR, Mead JG, Katona S (1978) The right whale, Eubalaena glacialis, in the western North Atlantic. Rep Int Whaling Comm 28:303-312

Keilly SB, Bannister JL, Best PB, Brown M and others (2012) Eubalaena glacialis. IUCN Red List of Threatened Species. Version 2013.2. www.iucnredlist.org/details/ 41712/0 (accessed 19 March 2014)

* Ridgway MS (2010) Line transect distance sampling in aerial surveys for double-crested cormorants in coastal regions of Lake Huron. J Gt Lakes Res 36:403-410

Rolland RM, Hunt KE, Doucette GJ, Rickard LG, Wasser SK (2007) The inner whale: hormones, biotoxins and parasites. In: Kraus SD, Rolland RM (eds) The urban whale: North Atlantic right whales at the crossroads. Harvard University Press, Cambridge, MA, p 232-272

* Rolland RM, Parks SE, Hunt KE, Castellote M and others (2012) Evidence that ship noise increases stress in right whales. Proc R Soc B Biol Sci 279:2363-2368

Kolland RM, Schick RS, Pettis HM, Knowlton AR, Hamilton PK, Clark JS, Kraus SD (2016) Health of North Atlantic right whales Eubalaena glacialis over three decades: from individual health to demographic and population health trends. Mar Ecol Prog Ser 542:265-282

Stone GS, Kraus SD, Prescott JH, Hazard KW (1988) Significant aggregations of the endangered right whale, Eubalaena glacialis, on the continental shelf of Nova Scotia. Can Field Nat 102:471-474

* Taylor JK, Kenney RD, LeRoi DJ, Kraus SD (2014) Automated vertical photography for detecting pelagic species in multitaxon aerial surveys. Mar Technol Soc J 48: $36-48$

* Thomas L, Buckland ST, Rexstad EA, Laake JL, Strindberg S, Hedley SL, Burnham KP (2010) Distance software: 
design and analysis of distance sampling surveys for estimating population size. J Appl Ecol 47:5-14

Van der Hoop JM, Moore MJ, Barco SG, Cole TV and others (2013) Assessment of management to mitigate anthropogenic effects on large whales. Conserv Biol 27: 121-133

Van der Hoop JM, Vanderlaan AS, Cole TV, Henry AG and others (2015) Vessel strikes to large whales before and after the 2008 Ship Strike Rule. Conserv Lett 8:24-32

Waring GT, Josephson E, Maze-Foley K, Rosel PE (eds) (2015) US Atlantic and Gulf of Mexico marine mammal stock assessments - 2014. NOAA Tech Memo NMFSNE-231. NMFS, Woods Hole, MA

Weilgart LS (2007) The impacts of anthropogenic ocean noise on cetaceans and implications for management.

Editorial responsibility: Ana Cañadas, Madrid, Spain
Can J Zool 85:1091-1116

* Weinrich M, Kenney R, Hamilton P (2000) Right whales (Eubalaena glacialis) on Jeffreys Ledge: a habitat of unrecognized importance? Mar Mamm Sci 16:326-337

Whitt AD, Dudzinski K, Laliberté JR (2013) North Atlantic right whale distribution and seasonal occurrence in nearshore waters off New Jersey, USA, and implications for management. Endang Species Res 20:59-69

Winn HE, Price CA, Sorensen PW (1986) The distributional biology of the right whale (Eubalaena glacialis) in the western North Atlantic. Rep Int Whaling Comm Spec Issue 10:129-138

*Winn HE, Goodyear JD, Kenney RD, Petricig RO (1995) Dive patterns of tagged right whales in the Great South Channel. Cont Shelf Res 15:593-611

Submitted: September 15, 2016; Accepted: March 17, 2017

Proofs received from author(s): July 10, 2017 